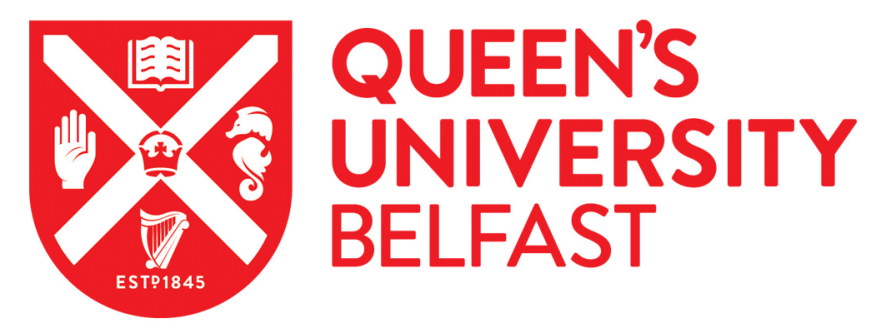

\title{
Temporary institutional breakdowns: the work of university traditions in the consumption of innovative textbooks
}

Palmer, M., De Kervenoel , R., \& Jacob, D. (2017). Temporary institutional breakdowns: the work of university traditions in the consumption of innovative textbooks. Studies in Higher Education.

https://doi.org/10.1080/03075079.2017.1324840

Published in:

Studies in Higher Education

Document Version:

Peer reviewed version

Queen's University Belfast - Research Portal:

Link to publication record in Queen's University Belfast Research Portal

Publisher rights

(C) 2017 Society for Research into Higher Education.

This work is made available online in accordance with the publisher's policies. Please refer to any applicable terms of use of the publisher.

\section{General rights}

Copyright for the publications made accessible via the Queen's University Belfast Research Portal is retained by the author(s) and / or other copyright owners and it is a condition of accessing these publications that users recognise and abide by the legal requirements associated with these rights.

Take down policy

The Research Portal is Queen's institutional repository that provides access to Queen's research output. Every effort has been made to ensure that content in the Research Portal does not infringe any person's rights, or applicable UK laws. If you discover content in the Research Portal that you believe breaches copyright or violates any law, please contact openaccess@qub.ac.uk. 
Temporary Institutional Breakdowns: The Work of University Traditions in the Consumption of Innovative Textbooks

Mark Palmer $^{1 *}$, Ronan deKervenoael ${ }^{2}$ and Dimitry Jacob ${ }^{3}$

${ }^{1}$ Queen's University Management School

Queen's University Belfast

Riddel Hall

185 Stranmillis Road

Belfast

Northern Ireland

BT9 5EE

m.palmer@qub.ac.uk

${ }^{2}$ Sabanci University, School of Management, 34956 Istanbul, Turkey

Email: dekervenoael@sabanciuniv.edu Tel: 0090 (216) 483-9704

${ }^{3}$ Queen's University Management School

Queen's University Belfast

Riddel Hall

185 Stranmillis Road

Belfast

Northern Ireland

BT9 5EE

*Corresponding author 


\title{
Temporary Institutional Breakdowns: The Work of University Traditions in the Consumption of Innovative Textbooks
}

\begin{abstract}
Universities are rich in both tradition and innovation. This study explores a temporary institutional breakdown when a radical pedagogic innovation meets institutionalised university traditions. The study employs a Reader-Response Theory, a prominent school of literary criticism, of two textbook innovations within a university establishment which had a distinct tradition to research beginning in the early 1960s. The findings suggest that the temporary institutional breakdown provides a powerful medium to understand the work of university traditions in the consumption of innovative textbooks. We show that in the consumption of pedagogic innovation, the recipients are not passive but are coconstructors of university tradition defence, via the articulation of values, boundary containment and identity work. We identify, moreover, four types of readings of the pedagogic innovation - interpretative, instrumental, inversive and reflexive. The findings also reveal three distinct forms of tradition vocabularies employed in pedagogic innovation - breach concerns, redress articulation and reintegration epistemology. Overall, the findings contribute to a better understanding of pedagogic innovation and university traditions.
\end{abstract}

Key Words: Tradition, pedagogic innovation, institutions, reader response, consumption 


\section{Introduction}

Universities are rich in both innovation and tradition. Both are often researched, yet studied separately, however. To be innovative, is often the 'first mission' and function of the Higher Education Systems and is often canonized with technophilic discourses (Hannan, English and Silver, 1999; Tight, 2011; Marshall, 2016), with the pejorative of the modern (Mathias and Rutherford, 1983). Pedagogic innovation here means new to the university, rather than new to the world (Birkinshaw, Hamel and Mol, 2008). In contrast, the pejorative of university traditions is that which is archaic (e.g. Oxbridge boat races), predominantly hinged upon the visual quaint imagery that combines rites, rituals, age, play, aesthetics and grand gestures (Dacin and Dacin, 2007; Lok and De Rond, 2013). These images carry nothing of 'the everyday' or 'the familiar' of academic work, nor do they radiate with the powerful effects of university traditions. University traditions, therefore, are seen as something to admire, bask in, a rite of the familiar, something that marketing enacts through the retelling of stories about 'the university Great, the Good and the Successful'. In this respect, university traditions are rather narrowly stereotyped and, consequently, have received little research attention.

From the standpoint of pedagogic innovation, there exists a strong imperative to introduce innovations designed to inculcate new attitudes, values, policy priorities and self understandings among educationalists (Berg and Östergren, 1979; Johnstone and Sharp, 1979; Williams, 1991; Barnett and Brown, 1981; Rudderford, 1992; Findlow, 2008; Ylijoki, 2013). This academic work has made the field aware of journeys that innovations make; the 'science' to 'technology' and to 'social progress' - where science invents, industry applies and society conforms is one journey that innovations make outside universities. To understand how individuals and universities respond to such innovations, however, it is useful to consider the inner university workings that are entwined in, and become salient during, the actual everyday consumption of pedagogic innovation. Here, there is a curious absence of the role of institutional human actors - the living beings such as students and academics whose actions, emotions, motivations, rhetoric - shape pedagogic innovation. This omission might, in part, be attributed to the dominant industrial economic foundations of innovation research and the various ways in which Michael 
Porter's work pervades much of the thinking on innovation as an attempt to create competitive advantage. This perspective has arguably presented an abstract, detached and deterministic (science push) account of pedagogic innovations, portraying institutional human actors as 'docile' and reacting to a 'given' innovation imposed upon them (Rudderford, 1992), as part of a generally distributed acceptance model (Saad, Guermat and Brodie, 2015), or as a pedagogic change and fashion (Badat, 2009).

From an institutional standpoint, by contrast, literature in higher education (Berg \& Östergren 1979; Findlow 2008), has provided insights into the way that innovation is a tentative social accomplishment dependent upon traditional institutional practices as well as consumption spaces (Badat, 2009; Marshall, 2016). Here, an academic tradition is seen as a source of continuity with the past or as cultural inheritance (Shils, 1981). The notion is quite broad and could mean anything that is passed down or inherited to the present. For Shils (1981:12), traditions incorporate a variety of beliefs, objects, memories, imagery, practices and institutions. University traditions are most notably visible when celebrated in playful student rite of passages (see Dacin and Dacin's (2007) account of the university bonfire at the University of Michigan, or Dacin, Munir and Tracey's (2010) study on formal dining at Cambridge colleges). Much less visible is how those university traditions pervade facets of everyday academic work.

To better understand how the work of university traditions can be found or created in innovation practice requires, according to Sandberg and Tsoukas (2011), studies to access and explore temporary institutional breakdowns. Temporary institutional breakdowns are interrupted openings of existing institutional orders in the internal workings of a practice (Sandberg and Tsoukas, 2011). This concept posits that whenever the novelty of a practice such as a pedagogic innovation is introduced -i.e., those that "fail to reproduce previously legitimated or taken-for-granted actions" (Lawrence and Suddaby, 2006, p. 217) - temporary institutional breakdowns occur and "practitioners enter into the involved thematic deliberation mode of engaging with the world, through which they pay deliberate attention to their practice" (Sandberg and Tsoukas, 2011). That is to say, a pedagogic innovation practice brings about "a publicly visible infraction of routines ordinarily held to be binding" (Turner 1988, 34), and insightful moments when things do not work as anticipated (Sandberg and Tsoukas, 2011). However, as 
Winograd and Flores (1987) note, "a breakdown is not a negative situation to be avoided, but a situation of non-obviousness" (1987: 165) - the recognition that something is missing or is not quite right, with the result that some aspects of the relational whole come to the fore.

This paper therefore aims to investigate how work rooted in institutional traditions imprints the consumption of pedagogic innovation in a university. In order to understand the process by which traditions pervade academic work, we study one institutionalized university tradition - the textbook within a university, which had a distinct tradition to research beginning in the early 1960s. While Gutenberg's invention of the printing press in 1440 and subsequent improvements to printing press technology has affected textbook markets and production quality over the centuries, and although the development new online teaching platforms, e-reading devices, book streaming services and social forums within the book market, the art of writing, illustrating and binding have remained valuable forms of cultural expressions and an age-old traditions (Sapiro, 2010). Within these combined traditions, we study how individual students work come to experience, know and accept or challenge institutionalized textbook traditions. It is at this human level of subjectivities that we conceptualize pedagogic innovation, arguing that this is where the specific effects of institutional traditions are felt most strongly. The paper takes a Reader Response Theory approach to understanding pedagogic innovations, studying two examples of textbooks, both of which, when adopted, reflect novel, experimental and radical ways of thinking about and exploring subjects in non-conventional ways, and the associated temporary breakdowns that generates. For the analysis we have selected two novels in the writings of Eliyahu M. Goldratt and Jeff Cox's "The Goal” (Goldratt and Cox, 2004) and Stephen Brown's "Agent and Dealers" (Brown, 2008) which delve into, and transcend, the boundaries between the private and public lives of managers and individuals, challenging the dispassionate, rational and technical phenomenon of management. We focus on these novels not because they accurately represent the 'empirical reality' of the subject, or but rather because of their tendency to exaggerate and clash with institutionalized textbook and university traditions (DeCock and Land, 2005). These are invented stories - fictionalized and therefore depart from the traditional law-like textbooks and are exemplary radical pedagogic innovation. We would argue, the novels, when used in practice, produced a temporary institutional 
breakdown, offering an understanding of pedagogic innovation at the level of individuals working in emergent temporary breakdown conditions when it meets the internal workings of university traditions.

The structure of the paper proceeds as follows. We begin with the existing literature on the role of traditions in higher education settings and argue that in such conditions, forms of traditions are tentative and contested. We argue that pedagogic innovation is the product of the interactive practice between higher education institutions and 'lived' consumption experiences. After considering one particular institutionalized tradition - the textbook - we retheorise pedagogic innovation as an interactive consumption space with associated discourses. The methodological approach taken is then outlined. Following on, we outline the findings of the study and we conclude by drawing out the implications for this study.

\section{Work of University Traditions}

The concept of tradition as articulated in the wider literature by Soares (1997) in the following way: " a living social tradition requires a distinct social group with a common identity derived from an interpretation of its past, whose collective memories have some objective expression in the material environment, and whose activities are guided by a spirit of continuity" (1997:16). Reporting of university traditions exemplifies a tendency to emphasize the playful student rite of passages, including intellectual games (e.g. MIT's college tradition of playing hacking pranks); sporting events (eg. Oxbridge boat races), food (e.g. food dining at Oxford College), frivolities (e.g. nudity shenanigans at Yale while handing out confectionary), or at graduation (e.g. graduates throwing their caps in the air at the end of the ceremony). Traditions are not limited to foreground and playful rite of passages, however. They also pervade more 'backstage' spaces and many facets of academic work, including the broader civic work in society and national innovation systems (Saad, Guermat and Brodie, 2015), pedagogy (Petersen, 2014), research (Berg and Östergren, 1979) and administration (Rudderford, 1992). These traditions can shape the specific practices of universities such as lecture delivery modes (Goldfinch, 2006), quality assurance initiatives (Findlow, 2008) textbook (non-)adoption (Palmer et al 2013), university-industry collaborations (De Silva, 2015) and admissions-recruitment activities (Brändle, 2016). 
Tradition debates are notably visible in the role of the higher education system (HES) in the production of national innovation (Saad, Guermat and Brodie, 2015). Saad, Guermat and Brodie's (2015) discuss the traditional civic role of universities and mechanisms through which this happens (e.g. traditionally supplying human capital and producing useful knowledge that supports innovation and economic and social development. A related research avenue has studied how government policy challenges traditions by promoting universities are, like business enterprises and wealth creators, with much discussion in cognate disciplines on the innovativeness of (non-) traditional university business models (De Silva, 2015).

The particular association of research tradition can be seen in terms of ruling systems of scientific paradigms - what is published and what is rejected, what research supported by grants and what cannot be followed up because of a lack of resources (Findlow, 2008). These research traditions can canonize ontological security, Mertonian normative ethos of academic science (Merton, 1942/1959) and intellectual esteem (e.g. Noble prize laureates, Schools of thought). Findlow's (2008) research study draws attention to innovation schemes, such as that of the HEFCE/Teaching Quality Enhancement Fund, which calls for funding applications centred on the traditional innovative models.

Traditions are also evident in the systems of pedagogy. A distinct area of enquiry has emerged to address pedagogic traditions in terms of traditional and non-traditional student routes to university (Brändle, 2016), non-traditional students and learners (Weil, 1986; Petersen, 2014), traditional versus nontraditional status and image (Isopahkala-Bouret, 2014), lecture and tutorial epistemologies (Goldfinch, 2006). Research-led university traditions are also linked with teaching-and-learning initiatives and how that is informed by academic research. While the uptake of the Internet suddenly made possible the adoption of online teaching platforms, e-reading devices, book streaming services and social forums, the traditional textbook remains an integral part of pedagogy. Academic traditions are thus used to define and differentiate academic subjects; the nature of ontology and epistemology and are interpreted in certain ways such as 'our' and/or 'their' tradition. Not only do the content of textbooks serve as 
introduce, create and preserve knowledge and subject doctrines and traditions (Allen and Press, 2002; Hackley, 2003; Richardson, 2004) but whole model systems or templates of pedagogy have been materialized through particular forms of textbooks (Palmer et al. 2013). Therefore, despite various types of disruptive technological innovations (eg. Ebooks), textbooks remain an enduring tradition of the institutional work of university lecturers.

Tradition is also brought into sharp light with specific university administrative systems. Universities go to great lengths to develop and promote various traditions within institutional scripts such as mission or vision statements and related policy documents. Other traditions revere innovation practices - initiatives such as innovation workshops, innovation labs and publication of exemplary 'best practice'. Mampaeya and Huismana (2016) study shows how traditions of the professional logic of the liberal academy visibly collided with market-oriented New Public Management (NPM) logics that constructs universities as businesses.

Although the various forms of traditions and out-workings of traditions have been discussed in the higher education literature, the internal working of university traditions is less well researched. In that regard, the institutional literature offers conceptual tools that could be useful in further understanding the links between traditions and university practice (Brennan et al, 1997; Findlow, 2008; Badat, 2009). Summarizing the distinguishing features of institutions, DiMaggio and Powell (1983) differentiate between core institutional elements containing a coercive (e.g. upheld by university bureaucracies), normative (e.g. evaluative norms of the scientific community), and mimetic (cultural-cognitive) dimension. In a normative institutional capacity, traditions provide not only continuity between the past and present but define what is deemed appropriate in the present. This can take the form of combined (non-) material as well as other elements including but not limited to a name, an identity, location, activity or imagery. However, a sense of identity with the past evolves and a sense of community or collective identity with the present emerges (Shils, 1981:14). The core and ancillary elements help to organize, transmit and reproduce 'institutional codes' (Friedland and Alford, 1991: 253), providing the 'basis for action' and structuring vocabularies that actors use to frame and make their activities 
meaningful to others (Mampaeya and Huismana 2016). This point attends not only to traditions as normative rules that maintain institutionalized role expectations in higher education settings, but also to a more transcendent notion of 'tradition' in terms of the cognitive 'mental models', prescribing what universities, departments and academics think and become the active and passive regulators in the reproduction and distribution of collective and shared views of the rules - or formal policies and procedures.

The analytical assumption is that traditions are cognitively transmitted and reproduced via the modalities of (in)formal scripts and talk. What, then, survives from the past often depends upon the perceived needs of contemporary university actors cognitively filtering their history to meet the needs of their present. As Williams (1977:115) writes of the traditions of the dominant hegemonic order, "what is thought of as 'the tradition' in practice is really only a 'selective tradition': What we have to see is not just 'a tradition' but a selective tradition: an intentionally selective version of a shaping past and a pre-shaped present, which is then powerfully operative in the process of social and cultural definition and identification." As such, traditions are perpetually vulnerable to change; via a renewal of university strategy (e.g. internationalization), public policy reform agendas (academic impact), new business models (e.g. shared university-commercial spaces), legitimacy crisis events (e.g. Funding) and transformation with innovation initiatives.

This perpetual vulnerability produces social tensions, contestation and, in certain circumstances, conflict between those social actors with particular sets of interests. In order to continue to function, these selective traditions for organizing teaching and learning requires, as Clegg (2010:5) explains, "a great deal of ordinary repair work of social breaches has to occur for a sense of normalcy to be sustained."

We have reviewed studies on the forms of university traditions and how institutional traditions are important for understanding the work of universities. And, whilst some researchers (Petersen, 2014; Isopahkala-Bouret, 2014; Brändle, 2016) have helpfully started to draw attention to the potential importance of the forms of traditions, limited theoretical analysis has been brought to bear on internal workings of university traditions. For although the concept of 'tradition' is still associated with the idea 
of something old and established from the past, an institutional analysis offers a theoretically rich way entailing selective and ongoing institutional maintenance work by individuals. That literature overlooks the humanness of the maintenance work involved at the level of the individual, and the suspicion of individuals to defend selective institutional traditions. In the next section, we further our re-theorization by framing the pedagogic innovation as a consumption practice with active associated discourses of institutional tradition.

\section{Pedagogic Production and Innovative Textbook Consumption}

Drawing on the German-American social psychologist Kurt Lewin (1890-1947), Berg and Östergren (1979) argue that innovation in higher education is a system with competing interests and opposing forces fighting for dominance around the equilibrium. Although innovation is sometimes on the face of it perceived as a neutral, Rudderford's (1992) initial research used the term emotively, acknowledging the human leadership side of innovation in the non-traditional staff development and appraisal scheme at the University of Birmingham. Similarly, Findlow (2008) provides insights into how the traditions associated with an innovation scheme can produce strong human emotions, specifically suspicion and skepticism. Other recent scholarship on institutions offers further insights into the humanness and the inhabited nature of institutions (Hallett, 2010; Hallett and Ventresca 2006). This inhabited institutional perspective sheds understanding on the agency of local actors to construct multiple and competing meanings through daily interaction - local revision - in ways that enact the institutional environment. Hallett (2010) finds that classroom mandates becomes negotiated among people in ways that redefine them as creating 'turmoil' and call into question their legitimacy.

In this respect, de Certeau's (1988) work may be useful in reconceptualising pedagogic innovation. de Certeau (1988) considers the notions of 'production' and 'consumption' in the framework of everyday activities. He argues for the idea that faced with an imposed 'production', 'consumers' are not passive or docile, but creatively respond to it through micro practices of resistance. Considering de Certeau's definition of 'consumption' as a creative act, it is interesting to study how students and academics 
'consume' pedagogic innovations such as novel textbooks. To conceptualize this idea, de Certeau explicitly used reading as a metaphor. While a textbook may be physically the same for everyone, what is read is a different experience for every individual, depending on what they bring into it and how they use it and connect it with their own lives. Creative consumption can thus be associated with acts of reading, using and transforming. The emphasis is not on the innovation, or its author, but its focus is with the reader. This accords with Reader Response Theory (Scott, 1994 Davis and Womack, 2003), which focuses on the readers' subjective experiences, the fact that poems, essays or novels are essentially inert until readers read them and breathe life into them. Of particular interest for reader-response researchers are the beliefs, values, expectations, understandings, hesitations, alterations, conjectures, self-corrections that accompany the flow of individual readers' reading experience, their response to the words on the page (Scott, 1994; Brown, 2005).

Such theoretical perspectives open up the idea that pedagogy innovation is rendered an extremely fluid concept, with dynamic actor responses and relationships that wax and wane within and between material (formal/informal) and abstracted forms, and consequent levels of visibility. It acknowledges that the "meaning" of any text is co-created by its author and reader. Alongside this, recent research conducted Callon (1986), and Latour (1992) and the Social Technology Studies field, more generally (Stirling, 2008), argues that the success of anything (e.g., an idea, a practice, a technology, an innovation) relies on its ability to tie the competing interests of systems with multiple actors together. However, studies highlight how traditional dominant elites are highly resistant to alternative framings, often opening up of dialogue and debate by, and about, innovations and related technologies, but also closing it down. Callon and Latour (1981, p. 279) refer to this as translation: "all the negotiations, intrigues, calculations, acts of persuasion and violence, thanks to which an actor or force takes on ... authority to speak or act on behalf of another actor or force." Drawing on this work, a Scandinavian Institutionalists school perspective (Creed, Scully, and Austin, 2002; Czarniawska and Sevon, 1996), emphasize this idea and explain how actors engaged in the negotiation of a discourse as they try to construct and bring to bear meanings that are in line with their context, values, views, interests and power. This translation model is premised on the discursive dimension, positing that when pedagogic innovations travel, a transformation of meanings 
from one context to another and from one language to another, occurs. Innovations are thus consumed and translated in institutional settings. That is, as the language of the pedagogic innovation travels from one context (e.g. the innovating lecturer and related champions) to another, (e.g. Programme Directors, Directors of Education, Teaching and Learning Committees, students), these are transformed from one language to another through a set of consumption and editing rules (Czarniawska and Sevon, 1996; Pipan and Czarniawska, 2010). Maguire and Hardy (2006) focus on how actors use discourses 'to fix understandings, shape interpretations, and justify practices in ways that are commensurate with their interests' (p. 10). Innovation consumption discourses may therefore be used by academics to confer ideas, aims, interests, claims, discipline, arrangements and alternatives as more efficient, less dominant, less dysfunctional, or less disruptive to the university.

While the literature on higher education studies entails diverse views on the nature of the academic work on innovation, to a large extent this research relates to the instrumental determination of pedagogy. We argue that inhabited institutionalism offers great potential for shedding new light on daily functioning of tradition work. Like Hallett (2010), we view universities as locales where individual students work come to experience, know and accept or challenge the legitimacy of pedagogic textbook innovation. While research has drawn attention to the visible ways in which institutional traditions and practice pervade innovation practice higher education, much less is known on the consumption and associated discourses. In each literature stream, we notice that humanness is seen as the outcome of the innovation practice rather than in the actual innovation consumption practice. We use this literature to frame our empirical study and the next section develops the methodological approach.

\section{Methodology}

\section{Institutional Setting and 'The University Tradition'}

The research was undertaken within a higher education institution that has had a long tradition of having a distinct approach to research beginning in the early 1960s with a first phase (Donaldson and Luo, 2014 for a useful overview), which grew to become known as the Aston Programme of studies. The phrase 'Aston approach' came to refer to a scientific style of research that featured quantitative variables and statistical data analysis. The intellectual tradition in which the Aston Programme was born was that 
industrial sociology was a dominant tradition and had affinities with the Human Relations School, which had spawned in England the Tavistock Institute, with its interest in autonomous work groups. Much of this tradition, it is argued here, is reflected in the teaching approach at the School. This study was undertaken over a four year period and 242 undergraduate students participated. Although this module is not representative of the overall school's programmes, the sample nevertheless provides an adequate mix of males and females, subject specialisms and academic experience to allow initial theorization. While use of classic works of literature as an effective tool in education has been well documented, not surprisingly, this approach were not evident at Aston and therefore the setting provided an theoretically rich setting for the study. The Aston approach is seen as a 'tradition' in the sense of a particular dominant and generalized genre of epistemology and acts in a sense of tradition. The positivist tradition at Aston Business School in this context is now applied on the way creators and performers exploit the constraints and opportunities in the form of the pedagogic innovation.

\section{The Reader Response Approach and Data Analysis}

The paper adopts a Reader Response Approach which is a technique that is a prominent in the school of literary (Davis and Womack, 2002; De Cock and Land, 2005). This technique focuses on the readers' subjective experiences through the act of reading a text or a textbook. To operationalize, each individual student was asked to select one of the textbooks and to read it. They were given the following brief:

Students will be asked to read and write extended introspective essays on their reactions to one of two innovative textbooks: "The Goal" by Eliyahu Goldratt in the operations field and "Agents and Dealers" by Stephen Brown.

We employed a Subjective Personal Introspection as the data collection technique for author's personal consumption experiences of pedagogic innovation. The analysis followed three stages. The first stage adopted Sandberg and Tsoukas' (2011) strategy of searching for temporary breakdowns, specifically by exploring students' and academic responses to (1) thwarted expectations,(2) the emergence of deviations and boundary crossings, and (3) awareness of differences. Here expectations are thwarted when students'

practice is disrupted because unintended consequences emerge, new realizations come about, or 
standards of excellence are not met. An example, "I cant believe we have been asked to read a whole textbook and in our final year of all years". Deviations emerge when new discourse items are introduced or new actions appear (e.g. reading, personal account, non-theoretical). This enables us to identify what work is significant to students (what matters to them). Finally, to explore when students and academics become aware of different practices (or the possibility of different practices) and how they respond to awareness of different practices (e.g., the resistance, ambivalence, or acceptance different practices may evoke) reveals what is significant in their own particular practice. This stage adopts the spirit of Garfinkel's (1967) idea of deliberately creating a temporary breakdown or breach to reveal the taken-forgranted ways of doing things.

In the second stage of the analysis of reader response theory, we chose to follow Kets de Vries and Miller's (1987) rules of interpretation and to start by first looking for a thematic unity in the data. This methodological treatment enables us to get close to the 'lived experience' of the pedagogic innovation, so that we can keep our second hermeneutic (our interpretations of students' interpretations) as close to the data as possible (Giddens, 1991). At this stage our analysis relied on a process of abductive theorizing (Mantere and Ketokivi, 2013) where the initial inductive hunch or insight originating from the empirical data, which is then coded, categorized and progressively worked to a higher level of abstraction (Gioia, Nag and Corley, 2012). After numerous readings of the data (242 essays), the first stage of analysis was constructed around the traditions work responses. As we read it repeatedly and examined the discourse surrounding it, we identified eight forms of traditions work. Then, moving the analysis to a higher level of abstraction, the themes and the data extracts associated with them were compared and grouped into eight larger second-order thematic categories that appeared to capture the meanings of the data. In a process similar to that proposed by Corley and Gioia (2004), extracts from the essays were coded systematically according to these 'first order' themes. We labelled these institutional defence traditions as articulation of values, boundary containment and identity work. 
After identifying these forms of 'traditions work', we then moved to an analysis of the readings of the text and were able to identify different forms of consumption of the pedagogic innovations. Each author independently coded the interview data, and after comparing and discussing the different categories developed, we agreed that four common generic patterns in these readings captured most of the data. We then matched our understanding of the structure of the text (forms of work) with students' readings (forms of consumption as interpretative, instrumental, inversive and reflexive). The constant interplay between the analysis of the textbooks comprise the articulation of the analysis.

The third, final stage, proceeded by a careful analysis of the keywords that were available in the 'university traditions register' and how these formed a coherent and powerful vocabulary. At this stage our analysis relied on adopting Turner' (1988) process model representation to structure and organise the discourse. In this, we clustered the keywords that formed distinct vocabularies and reflected different and distinct institutional discourse responses at each process stage. These were collected by two of the authors from nine meetings and discussions within two Staff-Student Committee Meetings, one Programme Review meeting, and two academic Appraisal meetings. Here we identified the dissociation discourse by which the speaker reexpresses ideas in order 'remove an incompatibility arising out of the confrontation of one proposition with others, whether one is dealing with norms, facts or truths' (Perelman and Olbrechts-Tyteca, 1969: 413). During this stage, the researcher used a reflective whiteboard exercise to discuss emerging themes and this subsequent feedback enhanced the interrogation and the presentation of the data. Throughout all of the stages, the findings are presented using thick, rich quotations relating to the actual introspective essay accounts of the students, which invite readers to assess the efficacy of the themes based on the evidence.

\section{Findings}

The findings span three inter-related stages and levels of analysis in the lived experiences: i) the institutional tradition work, ii) types of reading responses and, iii) and the institutional administrative response. From the reader responses, we see how students' reacted to both textbooks, what they made of them, and how the textbook became intertwined with the patterns of their university consumption 
experiences. The first part of the analysis of introspective accounts with students revealed three primary dimensions of tradition work: articulation of values, boundary containment and identity.

\section{Stage One: Tradition Work}

\section{Articulation work of values}

The first theme to emerge is the way that the reader responses related to the articulation of values. The students' accounts initially place an emphasis on articulating the value of their work, appealing to authoritative value drawn from what traditions, in order to delegitimize the new approach.

Formulaic conformity work. In the consumption mode responses, there was a conscious effort to conform to habitual formulaic templates. When confronted the threat of radical pedagogic textbook student, a dominant discourse emerged labelling it as a 'peculiar oddity', a 'weird task' or 'a bizarre concept'. These assertions recruited like-minded individuals, in an effort to reset old rules, regain familiarity and build associations with the old ways of doing things:

"The idea of this assignment makes me feel incredibly uncomfortable. I'm very much a 'think inside the box' sort of girl - that is how we have been schooled here. Familiar formats and I'm organized for that routine. The box is familiar and it's safe." S34

"...I'm listening to "We live on fascination" (Fascination, Alphabeat) and realise that the reason I'm fascinated by this assignment is because it's different to anything I've ever done before and I'm outside of my comfort zone..." S5

"What a strange task to be set. Ok, so what the hell am I supposed to do with that? No structure guidelines, no boundaries, no referencing... and a loose guideline of 2500 words within which to do it. I had to actually fight with myself to sit down and start this essay". S12

"This is a weird task - I don't understand why such lecturers don't stick to the way things are. This has put 'the cat among the pigeons' ...[and]... having no rules makes it chaotic and I don't like this feeling. All of the other modules have pages and pages of specifications, requirements and rules; I have become normalised in this and it allows for a fixed set rules and therefore solutions. Not here, I have been cut adrift in the large sea of pages, with only a limited vocabulary - SOS.” S247

"I start with a confession, of which I am rather ashamed about, and this confession is that after talking with my fellow students about the task in hand, my initial positive outlook started to alter 
leaving me somewhat apprehensive. This came about as I found myself observing the sheer panic of some of my friends and listening to their ramblings about the task, and I am very reluctant to admit I caught their bug. Despite the fact I felt so positive before I spoke to anyone about this I still caught the negativity bug. This consisted of an infectious dose of apprehension and disbelief which stemmed from the fear of having no firm guidelines to follow for an assignment." S32

Getting to work on the new innovation meant, calling down on the traditional values of prescription, structure, rules and a strict adherence to the conventional formats. The old approaches were perceived to be more ordered, rational and logical.

Ideological rebuttal work. Students embrace and present an ideological rebuttal of the pedagogic innovation as means of signaling a renewed devotion to the traditional ideals and to interject a sense of stability into this destabilizing task. This detraditionalizing forces of the radical innovation led students to associate the task with a higher normative learning ideals and duty, all the while pointing to the degree of absurdism and stigmatization. The novelty of the pedagogic innovation is open to competing with other activities:

"As I get to chapter thirty one I get side-tracked again. Distractions are everywhere in life. I pick up my phone to look at the time and see there is a message. I reply and ten minutes later I get another message. ... The beep on my phone distracts me again as I notice my friend has said she is unable to go into town today. However, I must preserve as my family expect me to graduate." S49

Students rebel against the beliefs and values of new approach with claims of absurdity. Absurdism is the basis for the subtlest form of ideological rebuttal, because it disrupts conventional notions about meaning by questioning its very existence. It that sense it encourages perceivers to fill in whatever meaning they like:

"So would I have gone out and brought this book or even borrowed it from the library in the same way that I borrow textbooks to skim through for exam revision. No. I simply don't do novels of any sort. The mastermind behind novel textbooks has created a hideous monster that not even Dr Frankenstein himself could have imagined." S15

"I found myself skimming through the first few pages of each chapter because they were filled with pointless rubbish. This task is absurd. Stuff that wasn't even related to the book. Are all books like that? S164 
The pedagogic innovation becomes a modern drama which characterized by irrationally and events are deemed illogical. Sometimes the ideological battlefield was within, however, with some students finding it paradoxical.

"I noticed the usual chit chat with my friends and peers changing. Whereas I would usually base my topics of conversation around the latest celebrity gossip on heatworld, or which fabulous bar everyone was heading to tonight, I found myself discussing the book and the characters involved, which is where I became increasingly worried. Many of my peers seemed to be enjoying the book; they were full of creative and interesting ideas and seemed to be progressing well with their projects." S210

"I found myself enjoying the book. Then I made myself cross for enjoying it. Reading, I shouldn't be enjoying this reading task. Business is serious, my course is serious, universities are serious and I'm oddly having fun. Sometimes the book made me think this is wrong; this is final year and we shouldn't be set surprises and unconventional tasks. Several of my class mates have concerns about this - it is so left of field and has come out of nowhere." S34

Stigmatizing work. The students' accounts offered some insight into their stigmatizing work, particularly with respect to producing denigrating concerns, stereotypes and absurdity. Here stigmatation of the pedagogic innovation is understood as an attribute that is deeply discrediting and that reduces an individual from a whole and usual person to a tainted, discounted one (Goffman, 1957). In a remarkable extract, the extent to which the students were bound by their textbook stereotypes:

"I read the synopsis and quickly realized that I had massively assumed that it was a sort of Gordon Ramsey or Duncan Bannatyne style business autobiography, far from it in fact. It is actually an academic who seems to like fictional writing about business, weird. This is concerning and I have many concerns.” S121

"It is always said that 'men are logical and women are emotional' and I have always hated that. It's so sexist to presume that emotions take over when women get involved in a situation and I know a fair few males who can't think logically at all! However, I am a bit of an emotional rollercoaster through this book. One minute I'm impatient and frustrated with what's happening or the pace of the story and the next I feel sad for Alex and empathise with how hard he's working, yet can’t seem to fix his plant or please his wife." S35

"The book made me feel inadequate. Inadequate in the sense that everyone was diving into their books and coming up with outstanding ideas whilst I was lagging behind on chapter one. The best thing that came out of this book? A sense of achievement. This was never about the book or 
the assignment, this was about me. This was my Everest! This was about my journey. I had overcome my stigma." S54

This stigmatization work sought to marginalize and disqualify the activity pedagogic acceptance.

\section{Boundary containment work}

The second main theme to emerge is the way that the reader responses related to the boundaries and how those could be contained or shored up. The students' accounts offered some insight into the construction a social boundary in terms of expansion, expulsion and protective work.

Expansion work. In this dimension, students' accounts centre on how the radical nature of the innovation produces an awareness of the boundaries of their vocabulary, particularly with respect to the university tradition of reading:

"Reaching the end of the book I can't help but notice the feeling of disappointment inside me. I glance to my right and look at the pile of paper, the list of words that I looked up. I feel very self-conscious. How can I graduate with a degree in Marketing with such a lack of vocabulary? Am I kidding myself that I am worth a degree? How can I expect to succeed in a job?" S94

"It's funny how the smallest word can affect your train of thought - The library. Just the thought of it makes me incredibly uncomfortable. It always gives the impression of being a positive working environment; no phones, no food, no drink, no talking -no distractions. No fun. The library means serious business. This assessment is serious business and will require serious work in the library." S37

Expulsion work. In this dimension, the meaning of textbook is contingent on where the reading is carried out, as well as the location-related nuances around broader consumption, for example, the library, the commute to university, or in the home. The expulsion is this respect is a form of (quasi-)detachment from the object:

"When completing assignments such as this one I find it difficult to locate a space where disturbances can't bother me. For reading, I often find this outlet on the train. The textbook has followed me onto the train; I have little to do apart from read it. On this occasion, however, I put my bag into the overhead luggage compartment and well out of sight..." S19

"It is really weird how carrying the book around makes me feel so much better about not actually reading it. I am so glad it is not a textbook, well I suppose if it was, I would have the most toned arms on earth, like that cartoon, Johnny Bravo.” S23 
The textbook is consumed in a variety of institutions peripheral to the university learning environment and the degree to which it gained acceptance there was insightful. As one reader response account noted in relation to the family:

"I spend the night discussing the book with my family, all of whom think it's a bizarre concept for an educational book. Mum doesn't though. She disagrees and thinks it's a clever assignment because of the way the theoretical concepts are intertwined. Mum can't understand why I've turned this innocent book into a demon in my head." S39

Protective autonomy work. In this dimension, a common response relating to students' accounts pointed to how much reading is an inhabited tradition, constituting them in the context of protection and security and self-disciplining, autonomous subjects:

"I love to feel safe when reading and cuddling up with a duvet is what makes me feel secure. I feel that the duvet is protecting me from feeling weak and disheartened when I do not understand the complexity of the language; it cushions me from having a major fall. A comfort blanket also makes reading feel more achievable and I feel less vulnerable and ashamed of my reading ability." S10

"I have chosen to start reading my book on my bed, the quietest and comfiest place in my apartment that offers little distractions that I know will easily hinder my consumption." S168

\section{Identity work}

The final main theme to emerge is the way that the workings of identity in the consumption of the radical textbooks. While our analysis has focused on the textbook consumption, we note also that a key aspect of how tradition work was in the individual identities of the student.

Student identity work. Overwhelmingly, the radical innovation challenged what it meant to "be" a student at University. The novelty of the task and the prospect of failure construed for students what Giddens (1991) refers to as 'fateful moments' which threatened the 'protective cocoon' that maintained their quotidian 'ontological security', and which required a renewed sense of identity work to maintain that:

"What I realised the most was the book put me through so many emotions, which I didn't expect, but on reflection, it made me sad, angry, annoyed, happy, giggly, motivated, and helped me realise how childish I am at heart, and I love that about me. We have never experienced this at Aston before. There is an Aston way and this is not what we know it to be. It has made me rethink why im at this university and on this course..." S23 
“...from a young age my vocabulary has always been an issue for me. Although I was born in England my first language was Italian and whilst I embrace my Italian roots, they did not hold me in good stead at school. Some of my earliest memories are of me being ridiculed for speaking to my teachers in Italian. I remember the frustration I used to feel when I couldn't express

myself properly or understand the language my classmates could speak." S109

A telling point from the reader responses is the way that individuals do not just tell a single, coherent identity narrative. The identity constructions appear to be fluid, messy and dynamic throughout the consumption practice.

Metaphorical identity work. In the reader response essays, students' accounts show how the consumption of the radical pedagogic innovation is socially negotiated and commonly displayed some key discursive elements, which are typically expressed through the journey metaphor:

"Oh the memories of the dog-eared, graffiti'd old textbooks and those English literature lessons reading obscurities such as 'Of Mice and Men' and 'An Inspector Calls'. Worse still they were usually accompanied with some awful film adaptation which we watched in class at Christmas or towards the end of term as a 'special treat'." S25

"The start of a book has a great sense of familiarity with me. The description of Rogo walking into his plant and to his office transported my mind back to when I had to visit my Dad's work as a child. My father is the chairman of a West Yorkshire based plastics fabrication company, known as Chem Resist Ltd. They manufacture large chemical storage tanks amongst many other things and walking into his plant as a young boy made a very big impression on me. For whatever reason, usually during school holidays, I would have to spend the day with my Dad in his office." S56

"Reading the book made me miss my friends, work colleagues and way of life from my last year. It resurfaced a lot of feelings about me being there and being with different people and learning from them. I guess day to day university life is so busy I don't often get a chance to sit down and really reflect how important the last year has been for me." S1

\section{Stage Two: Readings}

The second part of findings we describe in more detail four modes of consumption of the textbooks that reveal how the textbook was viewed in the eyes of its readers. Each of these modes of consumption is associated with both of the textbooks. Table I summarizes these four 'readings'. 
Table I. Four readings of the Innovative Pedagogic Textbooks

\begin{tabular}{|c|c|c|c|c|}
\hline Reading & Interpretative & Instrumental & Inversive & Reflexive \\
\hline Use of textbook & Open & Strict and closed & Bounded & Double reflections \\
\hline $\begin{array}{l}\text { Focus of student } \\
\text { engagement }\end{array}$ & Multiple meanings & $\begin{array}{ll}\text { Assessment } & \text { performance } \\
\text { implications }\end{array}$ & Benchmarking & Internalizing \\
\hline $\begin{array}{l}\text { Sample } \\
\text { quotations }\end{array}$ & $\begin{array}{l}\text { "Much of our work is small } \\
\text { bite sized pieces of work, } \\
\text { presented in bullet points. This } \\
\text { assessment makes you think - } \\
\text { it is deep." } \\
\text { "After finding out about } \\
\text { Abby's poor relationship with } \\
\text { her family, it's made me think } \\
\text { how lucky I am to have a great } \\
\text { family. This made me think } \\
\text { further about them and tried to } \\
\text { formulate some emotions about } \\
\text { them. After a heated discussion } \\
\text { with my girlfriend, I soon } \\
\text { realised that they are the root of } \\
\text { all my problems! My emotional } \\
\text { incapability most likely stems } \\
\text { from the relationship I hold } \\
\text { with my family, we have never } \\
\text { been comfortable with } \\
\text { expressing perhaps even } \\
\text { slightly embarrassing feelings } \\
\text { and emotions." S147 }\end{array}$ & $\begin{array}{l}\text { "“I have been conditioned since } \\
\text { prep school to expect a certain } \\
\text { writing and presentation style } \\
\text { from my text books. I prefer the } \\
\text { clarity and accessibility shown } \\
\text { by lists and facts. The action of } \\
\text { imagining a context to better } \\
\text { remember theory myself, was } \\
\text { the key to relating to scenarios } \\
\text { that I easily understood. A fair } \\
\text { percentage of people will learn } \\
\text { and remember concepts more } \\
\text { easily with the aid of diagrams; } \\
\text { something that is not included } \\
\text { in Agents \& Dealers, and } \\
\text { doubtfully in much of this } \\
\text { genre. S48 } \\
\text { "I guess the book didn't mean } \\
\text { anything to me. They were just } \\
\text { words. Words strung together } \\
\text { to make sentences, Sentences } \\
\text { strung together to make } \\
\text { pointless paragraphs. I just } \\
\text { didn't believe it I suppose. } \\
\text { Despite the only similarity that } \\
\text { I was a student and the central } \\
\text { character was a student, it was } \\
\text { too farfetched. I guess I had } \\
\text { this pre consumed idea that I } \\
\text { wasn't going to enjoy the } \\
\text { assignment or reading the book } \\
\text { no matter how good it was. } \\
\text { That negativity stayed with me } \\
\text { straight to the end. I tried my } \\
\text { hardest to relate everything but } \\
\text { I feel that was my weakness." } \\
\text { S5 }\end{array}$ & 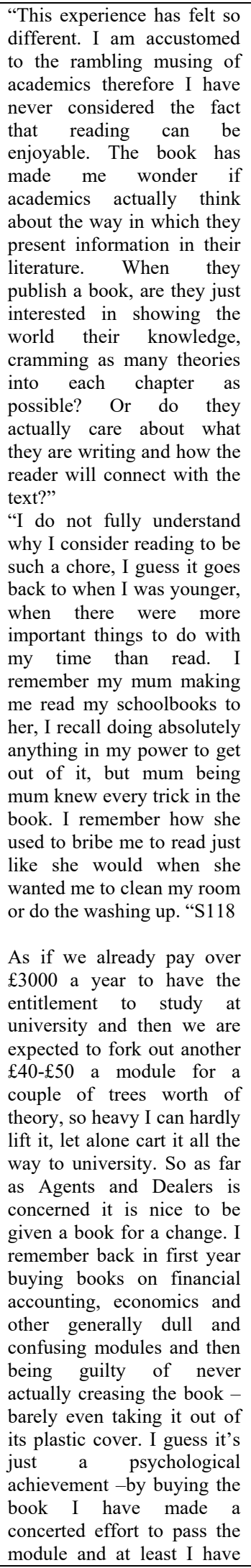 & $\begin{array}{l}\text { "my second lecture, } \\
\text { well that was really } \\
\text { obscure and off the } \\
\text { wall! Apparently, } \\
\text { we have to read a } \\
\text { book. Well that's } \\
\text { ok (or so I } \\
\text { thought!) but hey, } \\
\text { this isn't any old } \\
\text { book, this is a book } \\
\text { based on a book but } \\
\text { it's not a book } \\
\text { book, it's a } \\
\text { marketing book in } \\
\text { disguise!" S2 } \\
\text { "One thing I have } \\
\text { noticed as I am } \\
\text { reading this book is } \\
\text { that the way in } \\
\text { which I absorb } \\
\text { information from } \\
\text { paper has changed. } \\
\text { I think it might be } \\
\text { due to the way that } \\
\text { I read information } \\
\text { from the internet. } \\
\text { Whilst reading, I } \\
\text { find that my eyes } \\
\text { automatically stray } \\
\text { ahead by half a } \\
\text { page. This creates a } \\
\text { problem wuickest solution } \\
\text { means I can end up } \\
\text { reading a which sometimes } \\
\text { page without being } \\
\text { isn't the best." } \\
\text { able to remember } \\
\text { s129 rempletely changed } \\
\text { whe way I take in } \\
\text { information and I } \\
\text { can't help but think } \\
\text { this is a bad thing } \\
\text { as it always makes } \\
\text { actually a very } \\
\text { annoying habit to } \\
\text { have picked up } \\
\text { because I have to } \\
\text { to read now. The } \\
\text { internet concentrate }\end{array}$ \\
\hline
\end{tabular}




\begin{tabular}{|l|l|l|l|l|}
\hline & & & $\begin{array}{l}\text { the right intentions. } \\
\text { S25 }\end{array}$ \\
\hline Textbook seen as & Door opening up & Container & Comparable \\
\hline $\begin{array}{l}\text { Academic } \\
\text { Implications }\end{array}$ & Assessment flexibility & Reactivity & Benchmarking \\
\hline
\end{tabular}

Interpretative Reading - This form of consumption of the radical pedagogic textbooks is associated with that which produced new interpretations and reinterpretations the textbooks in a creative manner. Here, students' not only engaged with the written text, but also the textbooks' aesthetics, stories, characters, fiction, non-fiction, and imagery and also with their own surroundings in situ. The novel nature of the textbooks constituted a challenge for them ("I start to feel nauseous; millions of butterflies are flapping around in my stomach trying to find an escape route. I am so behind with my reading schedule and feel I cannot cope. I want to hurl the brainless, mind-numbing book on the floor. I hate it with a passion. All the book does is make me feel distracted, disturbed and distraught" S13). Specifically, the students' sought their own reinterpretation to fill in the blanks in the narratives, to open up the narrative constraints, to populate and imprint the broad story with their experiences. Thus, this group of readers was driven by a common concern with their own (re)interpretation of the textbooks' disparate elements, furthering open-endedness to capture the assignment and also learning: "Looking back, that voice between myself and the book did exist and caused me to drift off into my own thoughts or brought about emotions relating to the characters or story......"S26. Some were surprised and accepting, while others were left disappointed, or changed. Some interpretations started enthusiastically, making an immediate impression, but were then worn down by the frequent dictionary checking interruptions, the length and certain repetitiveness. Interpretative reading accounts were underlined by the importance of rhetorical questioning in the interpretative accounts.

Instrumental Reading - A second form of reading of both of the textbooks is associated with those students who focused strongly on the performance outcome. Final year students were under continuous pressure, they said, to perform. Here, some students intensified efforts to pin down and regulate the reading task of the textbook and indeed to suppress any ambiguities of the task. The language of clarity and precision to ensure the reading activity was linked with performance outcomes. The clear debt to the performance tradition, was on the extent of the reading task, rather than the reading per se. Here initial thoughts focused on whether they had made the right choice in terms of selecting textbook selection. Critical for the instrumentalist consumption mode, was to minimize the workload when considered against the efficiency and the pace of competing the assessment. Here, the radical innovation was 
conceived as a potential barrier to successful assessment task completion, particularly since the reading exercise was so extensive relative to the norms within the course. For some, the textbooks were mobilized within a place - a library, a lobby, a classroom, the home, the bedroom - so as to act as a consensus checklist against which students can reassure themselves. While for others they sought continuous academic justification in online peer to peer discussions, others sought affirmation with the module leader - individually and collectively - as well as more formally in terms of raising the justification and workload within Staff-Student Feedback Committees. More detail why this task was necessary, how it could be specified and prescribed more comprehensively and how the marking criteria could be qualified and even changed. For these students, the implication was that experimentation should happen on other programmes and not theirs. Any merits of the innovative pedagogic innovation and understanding of the purpose of the task, were supplanted by their imperative to complete the degree and the questioning agency whether such active reading was necessary. This group of readers engaged with the task in an instrumental 'bottom-line' key performance indicator way and linked this agenda strongly to their overall degree performance and the issue that they were in their final year. Final year to this group meant seriousness and that the higher significance afforded to the final year mandate and the associated traditions enabled students to produce tensions and challenge new innovation initiatives.

Inversive Reading - The third form of reading is termed inversive reading and is produced by students formulating images of the new textbook innovation by contrasting or benchmarking it with traditional existing textbooks, assessment requirements and expectations. With the radical pedagogic innovative textbooks, students were limited in terms of drawing on old and familiar frames of reference and priorities for the assessment. This was concerned with the discrepancy between espoused ideals of one set of traditional textbooks that had very clear identity markers and ways to follow to achieve goals. Such differentiation between formulated imagery and traditional templates implied a critique of that practice. In one respect, this inversive reading is associated with deconstructing the textbook through questions such as "novel" in what sense? Is it necessarily new or radical or different? Or how has its editing and interpretation affected the evidence, and with what assumptions or for what purpose? The upshot of considering such questions seems to be that all innovations are likely to be in one way or 
another vested by individuals and interested parties. In this consumption mode, the textbook is not read or used as an assessment document as much as a reengagement with the imagery evoked from yesteryear, particularly with respect to nostalgia of early childhood primary and secondary English language readings. The inversive readings thus produce a symbolic statement and historical context of the values of education. The best illustration of this value-based consumption of the textbook is found in the following excerpt: The textbook is therefore a repository of values that strengthens their engagement to quality and pedagogic involvement, spanning and that is taken by them as a symbol of their identity. In summary, these readers saw in the textbooks a restatement of the fundamental values of the university education system, connecting with other familiar education systems.

Reflexive Reading - A final form of reading identified in the discourse of student reader responses and is termed reflexive reading. Reflexivity is shown in how the students readings are self-aware and thoughtful about the situation they find themselves in and how they try to perform well. To this end, the students' accounts exhibited self- scrutiny in relation to self-doubts, self-consciousness, fearfulness and hypersensitivity. This was brought into sharp contrast in the distance between the daily life of innovation and the broader institutional conditions. Some readers applied this sense of sacrilege in failing to live up to the ideal of being a student or a final year student or even having a university degree.

One thing I have noticed as I am reading this book is that the way in which I absorb information from paper has changed. I think it might be due to the way that I read information from the internet. Whilst reading, I find that my eyes automatically stray ahead by half a page. This creates a problem which means I can end up reading a whole page without being able to remember what actually happened. It is actually a very annoying habit to have picked up because I have to really concentrate to read now. The internet has completely changed the way I take in information and I can't help but think this is a bad thing as it always makes me look for the quickest solution which sometimes isn't the best. S122

Reflexivity also manifested through 'practical-evaluation' (i.e. to respond to the demands of the present by making practical judgments among alternative trajectories of action) practical evaluation of the radical innovation pedagogic textbook and to get the task done. In sum, these readers muddle through:

"Consuming the book over the last three weeks was a mixture of being a battle and being quite fun. I have learned a little about production lines, but more importantly I have never really thought about how I consume a book, or anything else for that matter. I just do it. I have enjoyed being forced to think outside the box a little bit and take a different view on things." S98 
To sum up the analysis of different modes of consumption, for each of the four readings, traditions played a different role: firing the imagination for the interpretive reading, an obstacle in the performance trajectory for the instrumental reading, a source of comparison dispersion for inversive reading, or a practical means to get the job done for the reflexive reading. We now consider the consequences of the traditions work and the different modes of consumption, in relation how institutional administrative traditions supporting pedagogy bear down on pedagogic innovation consumption.

\section{Stage Three: Institutional Administrative Responses}

The third part of research highlights how the surrounding institutional administrative traditions supporting pedagogy bear down on students' consumption, but most powerfully as individual academic responds to the demands of both the novel arrival and prevailing institutional tradition.

Breach and concern discourse. The drama associated with radical pedagogic innovation begins with a breach of norm-governed social relations, "a publicly visible infraction of routines ordinarily held to be binding" (Turner 1988, 34). Such a transgression of norms was evident in the discourse that emerged from the vocabularies of concern. There were a variety of ways describing this. In some instances, the individual staff-student briefings as personal pronouns: "I am concerned", "I am a bit concerned", "I have areas of concerns" or "I am slightly concerned." The framing of concern is treated as serious, speculative, and potentially damaging to university reputation, rankings, or upsetting to students in particular. In other instances, a more institutional plural pronoun was emphasized - "we have some concerns". Either implicitly or explicitly, the new textbook format thus became a delegitimating performance device. Critically, it also spilled out into the university administrative system. In one insight, an interviewee admitted: "We are genuinely concerned with how this might affect the National student survey results." $A 3$ This discourse served to reveal interests and the stakes at play. As one senior appraising academic manager put it: "Why make life difficult for yourself? We are in mass education and so trying to produce individual thinkers is near impossible nowadays. It's a production line factory 
mindset. Appreciating the stark black and white reality will get you on...make you progress here.” A6 Whichever way the concern discourse is framed, it is done without either assuming or questioning the appropriateness of the pedagogic innovation. In this way this discourse is imbued with a special kind of neutrality and a I/we know best claim, reflecting the asymmetry of knowledge where the traditional welltested routes are known.

Redress and articulation discourse. Following Turner $(1988,34)$, a phase of redress in which representatives of the traditional order perform actions aimed at reintegrating the defiant actor and limiting the risk of the radical pedagogic innovation. These included the student representative feedback, staff-student feedback, student feedback survey and academic appraisal, all of which involved actors sensing, signalling and talking to, influencing, persuading and monitoring the situation. As one academic put it: "You need to butter the conservatives in here. They will have a certain view on how the world works and that's how they have gotten by and progressed. By challenging, or being seen to challenge, that will destabilize them."A4 In getting to grips with this, a second dominant tradition discourse emerged, that we termed articulation. Tradition articulation consists of all the words and talk needed to coordinate, sooth over and recover from the surprises, errors, tensions and conflicts: "I know you mean well and I can see the merit in your approach, but maybe there is another way of doing this. A way that is less disruptive." A2 The possibility that the concern may be misunderstood, misplaced, or that it is well founded and inaccurate, is illustrated by the following insightful remark: "These students are difficult to please. Upon hindsight maybe we should have reconsidered this. You are good at this, but how can we provide more space or a research lab for this idea." A1 As the above quotations illustrate, it provides 'a distancing provision' to the local or case specific circumstances in recognizing, weighing, and evaluating alternatives from conflicting sources. Critically, this discourse sought to smooth over the rough edges to allay heightened anxieties relating to the radical pedagogic innovation.

Reintegration and epistemological discourse. A social innovation drama comes full circle when the antagonists reach some resolution or working agreement to their conflict. This act of the drama presents 
"a reintegration of the disturbed social group" (Turner 1988, 34). It is argued that the consumption of the pedagogic innovation produced institutional responses in the form of epistemological discourse, creating additional emotional and social dynamics. Significant in this discourse was institutional steering $-\mathrm{a}$ collaborative coming-to-a-view that results from unpacking concerns and making sure that what is deemed an appropriate pedagogic innovation is signed off. The right method or way to do things: "I know how things work here”, "Did you check - it's normal to check and I know it might appear that way, but maybe just check the next time." A5 This epistemological discourse provide a method that is aligned with the way of taking the university tradition seriously while not having to presuppose their appropriateness within the broader institutional university system context.

\section{Discussion and Conclusions}

University traditions have been viewed as an archaic and sometimes extraneous playful incursion outside the serious business of everyday academic work. The findings suggest that the temporary institutional breakdown provides a uniquely powerful medium to understand that university traditions are, in fact, alive in the everyday academic work of universities. That is, we find it inescapable that the work of pedagogic innovation is an activity that is suffused with university traditions. In that respect, this study illuminates the internal workings of how new radical pedagogic innovations produce interrupted openings of existing institutional orders. These temporary institutional breakdowns - whether in relation to thwarted expectations, the emergence of deviations, or an awareness of differences - are essential to understanding the human consumptive dimensions of pedagogic innovation practice, when and why some appear and take root, while others do not (Hardagon and Douglas, 2001; Stirling, 2008). Rather than being detached from pedagogic innovations, the present study suggests university traditions are bound together, with both contingent upon, tentative and constantly open to change, in ongoing work, interpretations and institutional responses. Correspondingly, pedagogic innovations are open to reinterpretation, reworkings and development, and, on occasion, manipulation by the agency of university traditions and those who work, support, follow or control them (Honko and Laaksonen 1983). Far from being passive recipients, the students discursively co-constructed the pedagogic innovation 
consumption within the constitution of the university tradition, via the articulation of values, boundary containment and identity work. Indeed tradition work is imbued by human experiences that are subject to emotions such as anger, fear, surprise, disgust, happiness or joy, ease and unease.

The findings shows how there are constant efforts to revert to (re)claim traditions, particularly in its consumption, with human emotive side at the fore (O'Connor and McDermott, 2004). Such efforts tend to involve a good deal of romanticism about an imagined past, perhaps for familiarity, familiar paths and familiar pedagogies. Hughey (2012) identifies the narrative of belonging to involve 'overt othering' in which critics openly stigmatize, taint and thus delegitimise the pedagogic innovation and also the innovator. That 'overt othering' is deployed as a tactic in the students lived experiences of the radical pedagogic innovation, with a traditional institutional repository or toolkit of words and vocabularies available to them to frame and cast it. The findings reveal four types of readings of the pedagogic innovation - interpretative, instrumental, inversive and reflexive. Interestingly, the students formulated images and readings of the innovation assessment task in a series of 'fateful moments' which threatened the 'protective cocoon' and 'ontological security' (Giddens, 1991). This was particularly the case with instrumental and inversive readings.

The findings also reveal the institutional role of 'concern' for managing a range of issues to do with institutional interactions (Heritage and Lindstrom, 1998). Here, we find three distinct forms of tradition vocabularies employed in pedagogic innovation - breach concerns, redress articulation and reintegration epistemology. By using performative words (Austin, 1963), students and also the academics enhance their ability to 'bind' together the cohort and to address the institutional breach with traditional rules (Heaphy, 2013). In interactional terms, each keyword or turn-a-phrase actively functioned and suggested something adverse about the pedagogic innovation (Williams, 1981). This invites us to think symmetrically about agency: bringing radical pedagogic innovation to institutions does something performative. It shows the specific ways that university traditions actively confront, challenge and suppress pedagogic innovation (Lounsbury and Crumley, 2007). The inhabited institutions of the 
university, and the temporary institutional breakdowns in particular, as Gilbert (1997: 30) explains, "can tap our deepest emotions, and thus it can excite us to live more intense, self-aware lives." It suggests, and probably requires, a much more thorough awareness of both the ordering of interaction as well the ordering in interaction - and the associated traditions - from the micro-engagement of university social actors (Hallett, 2010). The present study therefore extends the institutional analysis of Lidstone (1995), Richards (2004) and Palmer, Simmons and Hall (2013) on the role of textbooks in university environments, specifically in relation to how institutions persist and self-reproduce through the presence and continued operation of self-regulating controls that increase the costs of nonconformity (Badat, 2009; Hallett and Ventresca 2006; Lok and DeRond, 2013). The study adds to our understanding of the more 'invisible work' (Leigh-Star, 1999:385) and/or the 'underground work' (Findlow, 2008: 325) between various university actors, resources and activities in the workings of institutions. Theoretically, it provides a more micro analytical theorizing of pedagogic innovation, moving from a linear conception to one that is multidimensional, emphasizing the humanness and wickedness of innovation within institutions (Marshall, 2014). Empirically, the study usefully pays specific attention in to how work rooted in institutional traditions discursively constructs the consumption of pedagogic innovation. In particular, the Reader Response approach provides insights into the beliefs of institutional carriers of the orthodox textbook tradition (Scott, 2003; Gosain, 2004). The article therefore provides insights into the temporary institutional breakdown moments in which a novel (artefact), the reader (student) the preexistent (institutional traditions) collide and intertwine. University traditions thus transform the substance of innovation work and have an impact on the pursuit of innovation itself.

Acknowledgements: The author is grateful to the support of the Provost and Deputy Vice Chancellor at Aston University, Professor Helen Higson, for her financial and academic support with this project.

\section{References}

Allen, M. and Preiss, R.W. 2002. An analysis of textbooks in interpersonal communication: How accurate are the representations? In M. Allen, R. W. Preiss, B. M. Gayle, and N. A. Burrell, (Eds.), Interpersonal communication research: Advances through meta-analysis: 371-87. Mahwah, NJ: Erlbaum. Austin J.L. 1963. How to Do Things with Words. London: Penguin.

Badat, S. 2009 Theorising institutional change: post - 1994 South African higher education. Studies in Higher Education. 34, Issue 4, pages 455-467 
Barnett, S.A. and Brown, V.A. 1981. Pull and push in educational innovation: Study of an interfaculty programme Studies in Higher Education, 6:1, 13-22,

Berg, B. and Östergren, B. 1979. Innovation processes in higher education Studies in

Higher Education, 4:2, 261-268.

Birkinshaw, J., G. Hamel and M. Mol. 2008. Management innovation, Academy of Management Review, 33, 825-845.

Brändle, T. 2016. How availability of capital affects the timing of enrollment: the routes to university of traditional and non-traditional students. Studies in Higher Education. Online. 1-21

Brown, S. 2005. Reconsidering the Classics: Reader Response to 'Marketing Myopia', Journal of Marketing Management, 21: 473-487.

Brown, S. 2008. Agents and Dealers. Marshall Cavendish Business.

Callon, M. 1986. Some Elements of a Sociology of Translation: Domestication of the Scallops and the Fishermen of St Brieuc Bay. in Power, Action and Belief: A New Sociology of Knowledge, edited by John Law. London: Routledge \& Kegan Paul. pp. 196-233

Callon, M. and Latour, B. 1981. "Unscrewing the Big Leviathan: How Actors Macro-Structure Reality and How Sociologists Help Them to Do So," in Advances in Social Theory and Methodology: Towards an Integration of Micro- and Macro- Sociologies, Karin Knorr-Cetina and Aaron Victor Cicourel, eds. Boston: Routledge \& Kegan Paul, 277-303.

Clegg, S. 2010. The State, Power, and Agency: Missing in Action in Institutional Theory? Journal of Management Inquiry, 19 (4), 4-13.

Colyvas.J and Powel, W.W. 2007. From Vulnerable to Venerated: The Institutionalization of Academic Entrepreneurship in the Life Sciences (PDF). Research in the Sociology of Organization 25: 219-259

Corley, K. G. and Gioia, D. A. 2004. Identity ambiguity and change in the wake of a corporate spinoff .Administrative Science Quarterly, 49, 173-208.

Creed,W.E.D. Scully, M.A Austin, J.R. 2002. Clothes make the person? The tailoring of legitimating accounts and the social construction of identity Organization Science 13 (5), 475-496

Czarniawska, B., and Sevón, G. 1996. Translating organizational change. Berlin: Walter de Gruyter.

Dacin, M.T. and Dacin, P. A. 2008. Traditions as Institutionalized Practice: Implications for DeInstitutionalization. The SAGE Handbook of Organizational Institutionalism edited by Royston Greenwood, Christine Oliver, Roy Suddaby \& Kerstin Sahlin-Andersson. pp. 326-352.

Dacin, M. T., Munir, K., and Tracey, P. 2010. Formal Dining at Cambridge Colleges: Linking Ritual

Performance and Institutional Maintenance. Academy of Management Journal, 53(6).

Davis, T. F. and Womack, K. 2003. Formalist Criticism and Reader-Response Theory, Basingstoke, Palgrave.

de Certeau, M. 1988. The practice of everyday life. University of California Press.

De Cock, C. and Land, C. 2005. Organization/Literature: Exploring the Seam. Organizational Studies. 27(4): 517-535.

De Silva, M. 2015. Academic entrepreneurship and traditional academic duties: synergy or rivalry? Studies in Higher Education. Online.

DiMaggio, P. and Powell, W. 1983. 'The Iron Cage Revisited': Institutional Isomorphism and Collective Rationality in Organizational Fields, American Sociological Review, 48:147-160.Furusten, S 1999. Popular management books: How they are made and what they mean for organizations. London: Routledge.

Donaldson, L. and Luo, B.N. 2014. The Aston Programme Contribution to Organizational Research: A Literature Review, International Journal of Management Reviews. 16, Issue 1, 84-104.

Findlow. S. 2008. Accountability and innovation in higher education: a disabling tension? Studies in Higher Education, 33:3, 313-329.

Friedland, R., \& Alford, R. R. 1991. Bringing society back in: Symbols, practices and institutional contradictions. In W. W. Powell, \& P. J. DiMaggio (Eds.), The new institutionalism in organizational analysis (pp. 232-263). Chicago and London: University of Chicago Press.

Garfinkel, H. 1967. Studies in ethnomethodology. Englewood Cliffs, New Jersey.

Giddens, A. 1991, Modernity and Self-Identity: Self and Society in the Late Modern Age, Stanford, CA: Stanford University Press, pp. 187-201.

Gilbert, D. R. 1997. A critique and a retrieval of management and the humanities. Journal of Business Ethics, 16, 23-35. 
Gioia, D. A., Nag, R. and Corley, K. G. 2012. Visionary ambiguity and strategic change: the virtue of vagueness in launching organizational change. Journal of Management Inquiry, 21, 364-75.

Goffman, E. 1959. The presentation of the self in everyday life. Doubleday. New York.

Goldfinch, J. 1996. The effectiveness of school-type classes compared to the traditional lecture/tutorial method for teaching quantitative methods to business students. Studies in Higher Education. 21(2), 207220.

Goldratt, E.M. and Cox, J. 2004. The Goal. Gower Publishing.

Gosain, S. 2004. Enterprise Information Systems as Objects and Carriers of Institutional Forces: The new iron cage? Journal of the Association for Information Systems, 5(4): 151-182.

in the transformation of institutionalized fields. Academy of Management Journal, 45: 58-80.

Hackley, C. 2003. We are all customers now: Rhetorical strategy and ideological control in marketing management texts. Journal of Management Studies, 40: 1325-1352.

Hannan, A. English, S. and Silver, H. 1999. Why innovate? Some preliminary findings from a research project on 'innovations in teaching and learning in higher education. Studies in Higher Education, 24:3, 279-289.

Hallett, T. 2010. The Myth Incarnate: Recoupling Processes, Turmoil, and Inhabited Institutions in an Urban Elementary School. American Sociological Review.75, 1: 52-74.

Hallett, T. and Ventresca. M. 2006. Inhabited Institutions: Social Interactions and Organizational Forms in Gouldner's Patterns of Industrial Bureaucracy. Theory and Society. 35, 2: 213-236.

Hardagon, A. and Y. Douglas. 2001. When innovations meet institutions: Edison and the design of the electric light. Administrative Science Quarterly, 46: 476-501.

Hardy, C., \& Maguire, S. 2010. Discourse, field-configuring events, and change in organizations and institutional fields: narratives of DDT and the Stockholm convention. Academy of Management Journal, 53(6): 1365-1392.

Heritage, J.C. and Lindstrom, A. 1998. Motherhood, medicine and morality: scenes from a medical encounter. Research on Language and Social Interaction, 3, 397-438.

Heaphy, E. 2013. Repairing the breaches with rules: Maintaining institutions in the face of everyday disruption. Organization Science. 24 (5). 1291-1335.

Honko, L. and Laaksonen, P. 1983. Trends in Nordic Tradition Research, Helsinki; Studia Fennica.

Hughey, M. W. 2012. Show Me Your Papers! Obama's Birth and the Whiteness of Belonging. Qualitative Sociology. 35:163-81.

Isopahkala-Bouret, U. 2015. 'It's considered a second class thing.' The differences in status between traditional and newly established higher education credentials. Studies in Higher Education. 40(7). 12911306.

Johnstone, A.H. and Sharp, D.W.A. 1979. Some innovations in university chemistry teaching Studies in Higher Education, 4:1, 47-54.

Kets de Vries, M. F. R. and Miller, D. 1987. Interpreting organizational texts'. Journal of Management Studies, 24, 233-47.

Latour, B. 1992. Where are the missing masses? The sociology of a few mundane artifacts, in Bijker, Wiebe E.; Law, John, Shaping technology/building society: studies in sociotechnical change, Cambridge, Massachusetts: MIT Press, pp. 225-258

Lawrence, T.B. and Suddaby R. 2006. Institutions and institutional work. In: S.R. Clegg, C. Hardy, T.B. Lawrence and W.R. Nord, Editors, The sage handbook of organization studies, Sage, Thousand Oaks.

Lidstone, J. 1995. Teaching with textbooks in undergraduate geography courses; guilt, gilt or gilding the lily? Journal of Geography in Higher Education, 19: 335-339

Leigh-Star, S. (1999). The ethnography of infrastructure. American Behavioural Scientist, 43(3), 377-91. Lok, J. and De Rond, M. 2013. On the plasticity of institutions: containing and restoring practice breakdowns at the Cambridge University boat race. Academy of Management Journal. Vol. 56, No. 1, 185-207.

Lounsbury, M. and Crumley, E.T. 2007. New Practice Creation: An Institutional Perspective on Innovation. Organization Studies, 28(7) 993-1012.

Mampaey, J. and Huisman, J. 2016. Defensive stakeholder management in European universities: an institutional logics perspective. Studies in Higher Education. Online

Mantere, S. Ketokivi, M. 2013. Reasoning in organization science. Academy of Management Review 38 (1), 70-89. 
Mathias, H. and Rutherford, D. 1983. Decisive factors affecting innovation: A case study Studies in Higher Education, 8:1, 45-55.

Marshall, S. 2016. Technological innovation of higher education in New Zealand: a wicked problem? Studies in Higher Education. 41(2), 288-301.

Merton, R.K. 1942/1959. Science and democratic social structure. In Merton, R.K. (ed.) Social theory and social structure. Revised and enlarged edition. Glencoe: The Free Press, 550561.

O'Connor*, G.C and McDermott, C.M. 2004. The human side of radical innovation Journal of Engineering Technology Management. 21. 11-30.

Palmer, M. Simmons, G. and Hall, M. 2013. Textbook (Non-) Adoption Motives, Legitimizing Strategies and Academic Field Configuration, Studies in Higher Education. 38 (4): 485-505.

Perelman C and Olbrechts-Tyteca L 1969 The New Rhetoric. Notre Dame: University of Notre Dame Press.

Petersen. E.B. 2014. Re-signifying subjectivity? A narrative exploration of 'non-traditional' doctoral students' lived experience of subject formation through two Australian cases. Studies in Higher Education. 39(5). 823-834

Pipan, T Czarniawska, B. 2010. How to construct an actor-network: Management accounting from idea to practice. Critical Perspectives on Accounting, 21(3): 243-251

Richardson, P.W. 2004. Reading and writing from textbooks in higher education: a case study from Economics, Studies in Higher Education, 29:505-521.

Rutherford, D. 1992. Appraisal in action: A case study of innovation and leadership. Studies in Higher Education, 17:2, 201-210.

Saad, M. Guermat, C. and Brodie, L. 2015. National innovation and knowledge performance: the role of higher education teaching and training. Studies in Higher Education, 40:7, 1194-1209,

Sandberg, J., and Tsoukas, H. 2011. Grasping the logic of practice: Theorizing through practical rationality. Academy of Management Review, 36, 338-360.

Sapiro, G. 2010. Globalization and cultural diversity in the book market: The case of literary translations in the US and in France. Poetics 38. 419-439

Scott, W.R. 2003. Institutional Carriers: Reviewing modes of transporting ideas over time and space and considering their consequences, Industrial and Corporate Change. 12(4): 879-894.

Scott, L. M. 1994. The Bridge From Text to Mind: Adapting Reader-Response Theory to Consumer Research", Journal of Consumer Research, 21. pp. 461-480.

Shils, E.C. 1981. Tradition. Chicago: The University of Chicago Press.

Soares, J. A. 1997. A reformulation of the concept of tradition. International Journal of

Sociology and Social Policy. 17(6): 6-21.

Stirling, A. 2008. Opening up and closing down: power, participation, and pluralism in the social appraisal of technology'. Science, Technology, \& Human Values, 33, 262-94.

Tight. M. 2011 . National innovation and the academic research enterprise: public policy in global perspective. Studies in Higher Education, 36:7, 869-871.

Turner, V.W. 1988. The Anthropology of Performance, New York: PAJ

Weil. S.W. 1986. Non-traditional Learners Within Traditional Higher Education Institutions: discovery and disappointment. Studies in Higher Education. 11 (3): 219-235

Williams, R. 1977. Marxism and Literature. Oxford: Oxford University Press

Williams, W. 1981. Of adversity and innovation in higher education Studies in Higher Education, 6:2, 131-138.

Winograd, T., and Flores, F. 1987. Understanding computers and cognition. Reading, MA: AddisonWesley.

Ylijoki, O-H. 2013. Boundary-work between work and life in the high-speed university. Studies in Higher Education. Vol. 38, No. 2, March, 242-255 